\title{
Late Pleistocene paleoproductivity patterns during the last climatic cycle in the Guyana Basin as revealed by calcareous nannoplankton
}

\author{
G.-E. López-Otálvaro ${ }^{1}$, J. A. Flores ${ }^{1}$, F. J. Sierro ${ }^{1}$, I. Cacho ${ }^{2}$, J.-O. Grimalt ${ }^{3}$, \\ E. Michel ${ }^{4}$, E. Cortijo ${ }^{4}$, and L. Labeyrie ${ }^{4}$ \\ ${ }^{1}$ Department of Geology, University of Salamanca, Plaza de la Merced, 37008 Salamanca, \\ Spain \\ ${ }^{2}$ Department of Stratigraphy, Paleontology and Marine Geosciences, University of Barcelona, \\ Martí i Franquès, Barcelona, 08028 Spain \\ ${ }^{3}$ Department of Environmental Chemistry, Institute of Chemical and Environmental Research \\ (IIQAB-CSIC), Jordi Girona 18, 08034 Barcelona, Spain \\ ${ }^{4}$ Laboratoire des Sciences du Climat et de l'Environnement, IPSL, Laboratoire Mixte, \\ CEA-CNRS-UVSQ, Parc du CNRS, 91198 Gif-sur-Yvette Cedex, France
}

Received: 6 February 2008 - Accepted: 12 February 2008 - Published: 17 March 2008

Correspondence to: G.-E. López-Otálvaro (gatsbyemperatriz@usal.es)

Published by Copernicus Publications on behalf of the European Geosciences Union.

\begin{abstract}
Variations in the assemblages and abundances of calcareous nannoplankton have allowed us to interpret changes in oceanic and atmospheric dynamics in the Guyana Basin, mainly linked to the southeast trades over the last climatic cycle.

Records of the paleoproductivity index of coccolithophores ( $N$ ratio) allowed us to monitor the nutri-thermocline fluctuations. Additionally, nannofossil accumulation rates vary closely with the $N$ ratio, indicating a strong correlation between these two paleoproductivity proxies. The dominance of upper (small Noelaerhabdaceae, Emiliania huxleyi and Gephyrocapsa oceanica), over lower photic zone dwellers (Florisphaera 10 profunda) during Termination II and interglacial substages 5.1 and 5.3 is related to eutrophic conditions due to a shoaling of the nutri-thermocline as a consequence of enhanced southeast Trade Winds. This activated an upwelling at the continental margin of the Guyana Basin. Low $N$ ratio values and the dominance of $F$. profunda over the glacial substages of MIS 5 and glacial MIS 2-4 are linked to a deep nutri-thermocline

15 (deep stratification of the mixed layer), at times of low influence of the southeast Trade Winds, and a weak upwelling. However, the $N$ ratio during MIS 2-4 was slightly higher than those seen for the MIS 4/5 boundary and glacial substages 5.2 and 5.4. These micropaleontological proxies follow the insolation at high northern latitude $\left(65^{\circ} \mathrm{N}\right)$ : the high $N$ ratio and NAR data from the Guyana Basin during Termination II and inter-

20 glacials 5.1. and 5.3 are correlated with high insolation values, and low values of the $N$ ratio and NAR during the MIS 4/5 boundary, glacials 5.2, 5.4 and MIS 2-4 are correlated with low insolation at the same latitudes. This situation suggests a link between the ITCZ, the southeast Trade Wind dynamics and the Northern Hemisphere climate changes during the last climatic cycle.
\end{abstract}




\section{Introduction and background}

Coccolithophorids are photosynthetic planktonic algae living in the photic layer of the ocean (Hibberd, 1976, Brand, 1994; Young, 1994; Winter et al., 1994) that play a significant role in carbonate precipitation (Siesser and Winter, 1994; Steinmetz, 1994).

5 The temporal and spatial distribution of coccolithophores may respond to major environmental factors in the upper oceanic layer such as temperature, nutrients, the trophic regime and sunlight levels (Brand, 1994; Young, 1994). For example, F. profunda, a phytoplankton species, thrives in the lower photic layer (Okada and Honjo, 1973; Okada and Mclntyre, 1977) at times of high nutrient concentration, pointing to a deep nutri-

10 cline (Molfino and Mclntyre, 1990a, b; de Menocal, 1995; Beaufort et al., 1997; Wells and Okada, 1997; Flores et al., 1999; 2000; Kinkel et al., 2000; Beaufort et al., 2001; Gibbs et al., 2004; among others). Thus, the relationship between dwellers from the upper photic zone and those from the lower photic zone has been used to reconstruct changes in nutricline depth caused by variations in the southeast Trade Winds in the

15 tropical Atlantic (Molfino and Mclntyre, 1990a, b) and in the Western Tropical Atlantic (Kinkel et al., 2000), as well as in the other parts of the ocean (Okada and Honjo, 1973; Young, 1994; Okada and Wells, 1997; Wells and Okada, 1997; Beaufort et al., 1997, 1999, 2001, 2003; Beaufort and Buchet, 2003; Flores et al., 2000; Liu and Herbert, 2004; Baumann and Freitag, 2004).

20 The production and sedimentation of coccolith-derived calcite in the deep ocean plays an important role in the carbon cycle through photosynthesis and calcification (Westbroek et al., 1993; Marsh, 2003; Brand, 1994, Young, 1994; Steinmetz, 1994). These organisms are one of the most important contributors to carbonate sedimentation in the open ocean and in continental slopes (Milliman, 1993; Steinmetz, 1994),

25 such as in the Guyana Basin (Shipboard Scientific Party, 2003), an area controlled by a setting of hemipelagic deposition. This region has been documented as the main route of interhemispheric heat flux exchange from the South to the North Atlantic.

The Guyana Basin is located in the area of annual shift of the Intertropical Conver-

gence Zone (ITCZ) that moves between $10^{\circ} \mathrm{N}$ and $5^{\circ} \mathrm{S}$ (Müller-Karger, 1989). The northward or southward position of the ITCZ causes a significant impact on water discharge from the Amazon and Orinoco rivers, as well as variations in the direction and speed of the Guyana Current (GC) and the southeast Trade Winds (Müller-Karger, 1989; Wilson et al., 2002; Ffield, 2005; Stramma et al., 2005) (Fig. 1).

During the boreal summer, the southeast Trade Winds are stronger and, the South Equatorial Current (SEC) and the North Brazilian Undercurrent (NBUC, which brings salty water from the South Atlantic) are well developed (da Silveira et al., 1994; Stramma et al., 1995, and Masson and Delecluse, 2000). Over that season, the west10 ward displacement of the SEC pileup surface waters along the eastern coast of South America deepens the nutri-thermocline in the Western Tropical Atlantic (WTA) (Hastenrath and Merle, 1987). When the SEC reaches South America, it splits into two branches: one turns southward, supplying the Brazilian current (BC), and the other one takes off towards the north and feeds the North Brazilian Current (NBC), which is called

15 the Guyana Current (GC) when it reaches the Guyana Basin (Fig. 1). The Intertropical Convergence Zone (ITCZ) is displaced to the northernmost position $\left(6^{\circ} \mathrm{N}-10^{\circ} \mathrm{N}\right)$, generating a wet season north of $\sim 5^{\circ} \mathrm{N}$ (Müller-Karger and Aparicio-Castro, 1994). The NBC (or GC) is mostly retroflexed, contributing to the North Equatorial Countercurrent (NECC) between $5^{\circ} \mathrm{N}-10^{\circ} \mathrm{N}$ (Müller-Karger et al., 1988), allowing anticyclonic rings to enter the continental margin and pass northwestward to merge with the Orinoco River plume (Müller-Karger, 1989; Ffield, 2005). These current rings transport and advect the Amazon River plume and, together with the NBUC, develop a zone of minimum surface salinity, warm temperatures and a shallower and stronger halocline, where the river flow is dispersed (Masson and Delecluse, 2000). The other component of the GC

25 is directed to the North Atlantic, transporting relatively warm and fresher waters via the Caribbean Sea (feeding Caribbean current, CC) and the Gulf of Mexico (where it supports the Gulf Stream, GS) (Showers and Bevis, 1988; Schmitz, 1995; Stramma and Schott, 1996; Lynch-Stieglitz et al., 1999).

During the boreal winter the northeast Trade Winds dominate and relocate the ITCZ 
to the southermost position $\left(0^{\circ}-5^{\circ} \mathrm{S}\right)$, causing dry conditions in the north of South America. River plumes decrease in intensity, and together with the GC, are mostly driven into the coastal area, carrying relatively colder and saltier waters to the North Atlantic. During this season, the NBUC mainly feeds the Equatorial Undercurrent

5 (EUC) at the equator and cannot cross the equator to the North Atlantic (Masson and Delecluse, 2000 and references therein). The actual mean position of the North Equatorial current (NEC) has been found north of $10^{\circ} \mathrm{N}$ (Lazar et al., 2002). This atmosphere-ocean dynamic in the WTA plays a major role in the cross-equatorial heat flux to the North Atlantic (Ffield, 2005), producing relatively cooler surface waters south of the equator, and warmer surface waters north of the equator $\left(>24^{\circ} \mathrm{C}\right)$ in the WTA.

This study focuses on a high-resolution micropaleontological analysis of coccoliths over the last climatic cycle. The primary goal is to reconstruct the patterns of calcareous nannoplankton production and their relationship with fluctuations in the nutrithermocline and ocean dynamics in the Guyana Basin (Fig. 1).

\section{Materials and methods}

\subsection{Core location and materials}

Core MD03-2616 was recovered in the Guyana Basin in the Western Tropical Atlantic (WTA) $\left(7^{\circ} 48.75^{\prime} \mathrm{N}, 53^{\circ} 00.80^{\prime} \mathrm{W}\right)$ at a water depth of $1233 \mathrm{~m}$, during the PICASSO Cruise by the Marion Dufresne R/V (Fig. 1). This area is characterized by the influence of the Guyana current, at the continental margin of French Guyana. The core shows an undisturbed high-quality sedimentary section of $39 \mathrm{~m}$ spanning the Pleistocene. It mainly consists of olive green silt and clay, rich in foraminifera and calcareous nannoplankton and with slight bioturbation levels and high organic matter remains (Shipboard Scientific Party, 2003). Here we report the uppermost $14.75 \mathrm{~m}$ (a detailed description 25 was reported by the Shipboard Scientific Party, 2003).

\subsection{Age model and biostratigraphy}

The age-depth assignments are primarily based on a series of 16 oxygen isotope control points performed on tests of the benthonic foraminifer Uvigerina peregrina. Stable isotope analyses were performed using an automated carbonate preparation line cou5 pled to a Finningan MAT 251 mass spectrometer at the Laboratoire des Sciences du Climat et de l'Environnement in Gif-sur-Yvette (France). Isotopic events were identified up to Marine Isotope Stage 6 , MIS $6(\sim 155 \mathrm{Ka})$, by comparison of the benthic $\delta^{18} \mathrm{O}$ from the Core MD03-2616 and the benthic $\delta^{18} \mathrm{O}$ stack of Lisiecki and Raymo (2005) (Fig. 2) (López-Otálvaro et al., 2008 ).

We analyzed the $>150 \mu \mathrm{m}$ fraction to detect the qualitative abundance of planktonic foraminifer species typical of the WTA. Study of planktonic foraminifer assemblages allowed the identification of the Ericson Climatic Biozones $W 1, X, Y, Z$ of Ericson and Wollin (1956) and the $Y_{P . o b l i q}$. of Kennett and Huddlestun (1972). In our record, Biozone $W 1$ was identified by the consistent and lower occurrence of the Globorotalia 15 menardii group from the bottom $(155 \mathrm{Ka})$ of the section studied up to $133 \mathrm{Ka}$. This event was dated by Kenneth and Huddlestun (1972) from $150 \mathrm{Ka}$ to Termination II $(128 \mathrm{Ka})$; i.e., slightly above ours. Biozone $X$ was dated from $133 \mathrm{Ka}$ to the middle phase of substage $5.1(84.3 \mathrm{Ka})$. Prell and Damuth (1978) reported the top of the Biozone $X$ at $85 \mathrm{Ka}$; i.e. slightly below ours. The $G$. menardii complex is absent from Biozone $Y$ (Ericson and Wollin, 1956; Kennett and Huddlestun, 1972), as we report here. The disappearance datum of Pulleniatina obliquiloculata ( $\left.Y_{\mathrm{P} \text {.obliq. }}\right)$ was recognized at $\sim 39 \mathrm{Ka}$, but this datum is diachronous across the tropical Atlantic (Prell and Damuth, 1978; Kennett and Huddlestun, 1972). Biozone $Z$ was identified close to the end of MIS 2 (over the latest Wisconsin) in agreement with Kennett and Huddlestun

25 (1972), although other authors have placed its bottom at the MIS 1/2 boundary (Ericson and Wollin, 1956; Maslin and Mikkelsen, 1997) (Fig. 2).

According to currently available data, the reversal in the abundance of the coccol-

\footnotetext{
${ }^{1}$ López-Otálvaro et al., in preparation, 2008.
} 
ithophore species E. huxleyi and Gephyrocapsa muellerae is not clear. Thierstein et al. (1977) placed this datum at around 73-85 Ka. The absence of Pseudoemiliania lacunosa, the relatively low abundance of G. caribbeanica species (less than $3 \%$ ), and the occurrence of both $E$. huxleyi and G. muellerae along the interval studied suggest 5 that our sediment sequence is younger than $268 \mathrm{Ka}$ (Fig. 2).

\subsection{Calcareous nannoplakton preparation and counting techniques}

Slides were prepared following the decantation technique outlined by Flores and Sierro (1997) to obtain quantitative measurements (coccoliths per gram, accumulation rates of coccoliths and coccolith-derived carbonate). These slides were examined at a 4-

$10 \mathrm{~cm}$ spacing (representing approximately $\sim 0.120 \mathrm{Ka}$ to $\sim 0.700 \mathrm{Ka}$ ) with a polarized microscope at $1000 \mathrm{X}$ magnification. 380 samples were examined, and more than 500 coccoliths were counted on each slide in order to identify the coccolith assemblage quantitatively.

Variations in the production of calcareous nannoplankton, and hence fluctuations in 15 the nutricline, were expressed as a function named the $N$ ratio (modified from Flores et al., 2000; López-Otálvaro et al., 2008), based on the relative proportion of taxa usually living in the upper photic zone (small Noelaerhabdaceae, E. huxleyi and G. oceanica; Okada and Honjo, 1973; Okada and Mclntyre, 1979; Giraudeau, 1992; Young, 1994; Okada and Wells, 1997; Wells and Okada, 1997; Flores et al., 1999, 2000, 2003;

20 Bollman et al., 1998; Beaufort et al., 1999; Beaufort and Buchet, 2003; Hagino and Okada, 2004, among others) versus the lower photic zone dwellers ( $F$. profunda; Okada and Honjo, 1973; Okada and Mclntyre, 1977; Molfino and Mclntyre, 1990a, b among others). High $N$ ratio values (close to 1 ) indicate a high production of upper photic species against the production of lower photic species, as result of a shallow nutri-

25 thermocline. Low $N$ ratio values (close to 0 ) reveal a proliferation of $F$. profunda, in agreement with a deep stratification and a deep nutri-thermocline (Okada and Honjo, 1973; Okada, 1980; Molfino and McIntyre, 1990a, b; Wells and Okada, 1997; Flores et al., 2000).

A qualitative preservation index of coccoliths, CEX', a proxy of the coccolith lysocline position (Dittert et al., 1999; Boeckel and Baumann, 2004), was used based on the relationship of the small Noelaerhabdaceae and E. huxleyi as the thinnest coccolithophoral species versus Calcidiscus leptoporus as a highly calcified species.

The accumulation rate of coccoliths (NAR, liths ${ }^{*} \mathrm{~cm}^{-2 *} \mathrm{Ka}^{-1}$ ) has been widely used by several authors as a reference for high paleoproductivity of coccolithophores and particle flux out of the mixed layer (Steinmetz, 1994 and references therein; Su, 1996; Baumann et al., 2004). This parameter was estimated following the standard method of Flores and Sierro (1997), and it involves knowledge of the absolute abundances of coccoliths, the sedimentation rate and the dry sediment bulk density.

\section{Results}

The small Noelaerhabdaceae, G. oceanica and F. profunda proved to be the dominant species in the calcareous nannoplankton assemblage. Gephyrocapsa muellerae and Umbilicosphaera sibogae species (Appendix B and C) were identified as impor-

15 tant secondary components. Additionally, Helicosphaera spp. and C. leptoporus were considered subordinate species because they were present in lower proportion (less than $2 \%$ ) along the record studied. U. sibogae was the most abundant species (up to $12 \%$ ) of the group of warm taxa, accounting for less than $4 \%$ and include Calciosolenia murrayi, Discosphaera tubifera, Neosphaera coccolithomorpha, Oolithothus spp., Pon-

20 tosphaera spp., Rhabdosphaera clavigera, Syracosphaera spp. and Umbellosphaera spp. U. sibogae was separated from this group to analyze its paleoecological behavior along the section studied (Appendix B). The preservation of coccoliths was good along the last climatic cycle, except during the cooler MIS 5.2 and MIS 5.4 and the end of MIS 5.5. Decreases in the CEX' index and marked increases in the relative abundances of

25 the most resistant species in the assemblage ( $G$. oceanica and $F$. profunda), at least during MIS 5.4 and later MIS 5.5, confirmed this situation.

Based on the temporal evolution of calcareous nannoplankton, the sedimentary se- 
quence was separated in two scenarios: Glacial MIS 6, interglacial MIS 5 and Termination II, and glacial stages $2-4$ and the Holocene (Figs. 3 and 4).

\subsection{Glacial MIS 6, Termination II and interglacial MIS 5}

Small Noelaerhabdaceae dominate the assemblage, showing high relative abun5 dances during MIS 6, the interglacial substages 5.1 and 5.3 and Termination II. By contrast, the relative abundance of $F$. profunda indicates a predominance of this species in the assemblage throughout the glacial substages of MIS 5, following an inverse trend to small Noelaerhabdaceae and G. oceanica (Fig. 3). The proportion of G. oceanica has low values and this points to moderate fluctuations during MIS 5, except during

10 the end of MIS 5.5 and MIS 5.4 (when the assemblage underwent dissolution, as seen by the low CEX' values, Fig. 4). Mild percentage peaks of G. oceanica are seen along the MIS $4 / 5$ boundary and glacial substage 5.2. The percentages of $U$. sibogae vary between $2 \%$ and $6 \%$, with maxima during interglacials $5.1,5.3$ and early 5.5 (Fig. 3 ).

Common high NAR values during MIS 5.1, 5.3 and early 5.5 are seen for small

15 Noelaerhabdaceae and U. sibogae. The former species also display high NAR values along Termination II and MIS 6. The NAR peaks of G. oceanica only occur during MIS 5.1 and early MIS 5.5, while the highest NAR of $F$. profunda occurs along MIS 5.2 and MIS 5.3. Owing to dissolution, all species show minimum NAR values throughout MIS 5.4 and late MIS 5.5 .

20 Stronger gradients of the main taxa are observed in the relative abundances of calcareous nannofossils (between $10 \%$ and $80 \%)$ and partial NAR values $\left(1 \times 10^{11}\right.$ and $1 \times 10^{9}$ liths ${ }^{*} \mathrm{pg}^{-} 1^{*} \mathrm{~cm}^{-2} \mathrm{Ka}^{-1}$ for small Noelaerhabdaceae; $8 \times 10^{9}$ and $1 \times 10^{8}$ liths ${ }^{*} \mathrm{pg}^{-1 *} \mathrm{~cm}^{-2} \mathrm{Ka}^{-1}$ for $\mathrm{G}$. oceanica; and $1^{*} 10^{9}$ and $3.5^{\star} 10^{10}$ liths $^{*} \mathrm{pg}^{-1 *} \mathrm{~cm}^{-2} \mathrm{Ka}^{-1}$ for F. profunda) during MIS 5 (Figs. 3 and 4).

The variation in total NAR is very similar to that of the $N$ ratio, showing stronger gradients between the interglacial and glacial substages of MIS 5 , with values between 0.9 to 0.2 for the $N$ ratio and, $1.2 \times 10^{11}$ and $1 \times 10^{10}$ liths $^{*} \mathrm{pg}^{-1 *} \mathrm{~cm}^{-2} \mathrm{Ka}^{-1}$ for the total NAR (Fig. 4).

\subsection{Isotope stages 2-4 and the Holocene}

During MIS 2-4 and the Holocene, dominant species exhibit less amplitude (lower gradients) but more frequent variability in their relative abundances than along MIS 5 . F. profunda is the most abundant species, showing stable values in its percentages (up

5 to $45 \%$ ). The proportions and NAR values of this species vary in the opposite sense to those of G. oceanica and small Noelaerhabdaceae (Fig. 3).

The relative abundances of $G$. oceanica (10-20\%) are lower than the steady proportion of small Noelaerhabdaceae (20-38\%), in spite of its slight increase in the former species during MIS 3. Higher NAR values of G. oceanica appear during early and late

10 MIS 3 and the Holocene. On the other hand, the stronger drop in the NAR values of small Noelaerhabdaceae during MIS 2-4 and the Holocene is comparable to the values found for the glacial MIS 5.2.

The percentage abundance of $U$. sibogae is somewhat higher during glacial 2-4 (values comparable to those of MIS 6) than during MIS 1 and MIS 5 . However, the vari15 ability in the NAR values of this species is similar between the Holocene, the boundary of MIS 5/4 and MIS 5.1.

Frequent and mild fluctuations in the $N$ ratio and total NAR occur throughout MIS 2-4 and the Holocene. They are comparable to those observed at the end of MIS 5.2 (Fig. 4). These parameters are strongly influenced by the dominant species in the assemblage and in consequence display low gradients during glacial MIS 2-4 (Figs. 3 and 4).

\section{Discussion}

\subsection{Productivity of calcareous nannoplankton}

The evolution of the calcareous nannoplankton assemblage (revealed by the $N$ ratio, 25 the NAR of individual species and the total NAR values) is mainly a response to a 
productivity pattern in the Guyana Basin (Figs. 3 and 4), but the production rate of calcareous nannoplankton is limited by the release of nutrients to the mixed layer (Young, 1994). The question thus arises as to which oceanic mechanism allowed the production of calcareous nannoplankton.

$5 \quad$ All proxies studied in Core MD03-2616 ( $N$ ratio, species percentages and NAR values) indicate a shallow nutri-thermocline and more nutrient-enriched conditions in the mixed layer during MIS 6, Termination II and the interglacial substages of MIS 5 (Figs. 3 and 4). This situation would have resulted in a higher primary production and eutrophic conditions, and such a scenario implies the influence of the southeast Trade Winds

10 blowing parallel to the coast (Gibbs, 1980), favoring upwelling and eastward water transport through the well-developed NECC (a situation analogous to the hydrological conditions prevailing during the boreal summer, Fig. 1). Moreover, during the glacial substages of MIS 5 , the data support a deeper nutri-thermocline and more nutrientdepleted surface waters, resulting in a lower primary production in a deep stratified

15 photic layer (Figs. 3 and 4). This scenario implies a weaker influence of the southeast Trade Winds in the Guyana Basin and the intensification of the northeast Trade Winds blowing perpendicularly to the coast (Gibbs, 1980). Enhanced northeast trades favor the piling up of surface waters dragged by the NEC and the disappearance of the NECC that transports water away from shore. Additionally, the ITCZ is shifted to a southward 20 position (between $0^{\circ}$ to $5^{\circ} \mathrm{S}$, Müller-Karger, 1989) and the $\mathrm{GC}$ follows a northwest direction (Fig. 1). Bassinot et al. (1997) and Vink et al. (2001) have suggested a southward latitudinal migration of the atmospheric and hydrographic circulation in the WTA during the last glacial and Vink et al. (2001) proposed a displacement of $6^{\circ}$ southward for the NEC during the same time. Similarly, Kinkel et al. (2000) recorded a shallow nutricline and high coccolithophore productivity along the interglacial times and a deeper nutrithermocline along the glacial stages and substages in the WTA during the last climatic cycle.

The glacial MIS 2-4 and the Holocene are associated with recurrent, steady and low amplitude variations in the shoaling/deepening of the nutri-thermocline, pointing to a

weak upwelling. This latter situation reveals the entrance of a mesotrophic regimen in surface waters as a result of the periodic variability of Trade Wind dynamics in the WTA (Peterson et al., 2000; Vink et al., 2001) (Figs. 3 and 4).

Gibbs (1980), Pujos and Froidefond (1995, and references therein) indicated sea5 sonal scenarios where southeast Trade Winds are enhanced and blow alongshore in French Guyana, favoring wind-induced upwelling in the basin. Their work was restricted to the equator and $5^{\circ} \mathrm{N}$. The geographic position of the core studied falls within the areas studied by those authors, and hence the same hydrological conditions can be considered (wind-induced coastal upwelling). This atmospheric dynamic displaces the

10 ITZC to a more northern position $\left(6^{\circ} \mathrm{N}-10^{\circ} \mathrm{N}\right.$ ), and permits the NBC (or GC) retroflection (Müller-Karger, 1989) and the formation of the NECC between $5^{\circ} \mathrm{N}-8^{\circ} \mathrm{N}$ (Busalacchi and Picaut, 1983). Additionally, other authors (Ryther et al., 1967; Hulburt and Corwin, 1969; Müller-Karger, 1995) have examined the occurrence of upwelling at the continental margin of the Guyana Basin $\left(7^{\circ} \mathrm{N} \pm 1^{\circ}\right.$, Müller-Karger, 1995; Wilson et al., 2002) associated with the origin of the retroflection of the NBC (GC), and with the enhancement of the southeast Trade Winds.

Furthermore, cool sea surface temperatures from the North Atlantic are in phase with changes in ice sheet volume, reflecting glacial-interglacial oscillations and controlling Trade Wind intensity (Manabe and Broccoli, 1985; Ruddiman and McIntyre, 1984; Rud20 diman et al., 1989). Changes in the temperature/pressure gradients between the North and South Atlantic affect the meridional wind component and define the latitudinal position of the ITCZ (Hastenrath and Greischar, 1993; Hastenrath and Druyan, 1993). This association accounts for the relationship between cold/warm periods in high latitudes in the North Atlantic and drier/wetter conditions over northern South America (Haugh

25 et al., 2001). Visual comparison of the $N$ ratio and NAR records with a northern insolation curve (mean insolation, 1 June to 30 September, $65^{\circ} \mathrm{N}$ ) reveals peaks in the production and accumulation rates of calcareous nannoplankton and a shallow nutrithermocline that follows the maxima in insolation at $65^{\circ} \mathrm{N}$. This correlation suggests a close connection between the shifts of the nutri-thermocline, Trade Wind dynamics, 
and the latitudinal migration of the ITCZ. Molfino and McIntyre (1990a, b) and Wolff et al. (1999) found that variations in the position of the nutri-thermocline are controlled by the Trade Winds in the eastern tropical Atlantic (but in contrast with the present findings in the WTA, they reported a shallow nutri-thermocline during glacial periods).

5 Variations in the position of the thermocline have been reported by Hüls and Zahn (2000) and Vink et al. (2001) in a nearby core taken from the Tobago Basin. These authors studied Core M35003-4, which was collected at $12^{\circ} 05^{\prime} \mathrm{N}, 61^{\circ} 15^{\prime} \mathrm{W}$ at a water depth of $1229 \mathrm{~m}$ (a similar water depth to Core MD03-2616;1233 m). They found the shallowest thermocline for MIS 3 ( $\sim 50 \mathrm{~m}$ depth) in comparison with the glacial MIS

102 ( $\sim 80 \mathrm{~m}$ depth) and the Holocene (150 $\mathrm{m}$ depth). Furthermore, Pailler et al. (1999) reported that the main thermocline is currently $150 \mathrm{~m}$ deep in a section of the WTA located between $0^{\circ} \mathrm{N}-45^{\circ} \mathrm{W}$ and $8^{\circ} 20^{\prime} \mathrm{N}-41^{\circ} \mathrm{W}$, which surrounds the core position of this study.

\subsection{River runoff}

15 Some authors have suggested that the main freshwater source that affects the WTA is the Amazon River, which is mostly responsible for the low sea surface salinity in the WTA (Masson and Delecluse, 2000) since the waters of the Orinoco flow downstream towards the Caribbean Sea (Ffield, 2005). Several authors have indicated that high abundances of phytoplankton are associated with higher seasonal river runoff and lower salinities in the northern Caribbean Sea $\left(14^{\circ} \mathrm{N}\right.$ and $\left.18^{\circ} \mathrm{N}\right)$ than in the typical waters of the WTA (Müller-Karger et al., 1989 and references therein).

Likewise, but addressing paleoclimatic changes at orbital scales, other studies have confirmed the northward position of the ITCZ along the interglacial substages of MIS 5 (in the Caribbean Sea, Martínez et al., 2007), and interglacial substages of MIS 3

25 (in the Cariaco Basin, Peterson et al., 2000; in the WTA and in the Tobago Basin, Vink et al., 2001), favoring the influx of river nutrients to the ocean and the configuration of an oceanic system that supports a superficial nutri-thermocline and consequently increased biological productivity in those regions. Similarly, Showers and Bevis

(1988) documented an increase in the Amazon River runoff during Termination I until 5-6 Ka B.P. Other authors have reported the southward geographic situation of the ITCZ over the last glacial and consequently drier conditions over northern South America (Kolla et al., 1979; Balsam et al., 1995), decreasing the influence of the river flow

5 system, deepening the nutri-thermocline and reducing bioproductivity (Peterson et al., 2000; Vink et al., 2000, 2001, 2002). According with these suggestions and the chlorophyll concentration data (primary distribution) presented by SeaWIFS Project (Fig. 1), the influence of an enhanced nutrient supply by rivers in the production of calcareous nannoplankton cannot be completely ruled out. However, there is no clear indicator within the association of calcareous nannoplankton able to account for a greater discharge from the Amazon during the interglacials and neither are there any indicators within the association to suggest relationships with variations in the salinity of surface waters. U. sibogae has been directly related to surface water salinity in the North Pacific (Roth and Coulbourn, 1982), has been found in warm oligotrophic waters (Okada and Mclntyre, 1979; Roth, 1994; Young, 1994; Böeckel and Baumann, 2004; Ziveri et al., 2004), but also in medium-to-high fertility waters (Roth and Berger, 1975; Roth and Coulbourn, 1982) with temperatures ranging from $18^{\circ} \mathrm{C}$ to $25^{\circ} \mathrm{C}$ (Mclntyre and Bé, 1967; Okada and Mclntyre, 1979). Additionally, G. oceanica has also been observed in relatively warm, highly saline and fertile waters (Winter, 1982, 1985; Mitchell-Innes

20 and Winter, 1987). However, U. sibogae and G. oceanica do not show a systematic correspondence with temperature or salinity. This implies that G. oceanica and U. sibogae respond to a productivity pattern rather than to a pattern of temperature or salinity, especially significant in MIS 2-4 (Fig. 3).

\subsection{Dissolution of calcareous nannoplankton}

25 Coccolith dissolution episodes (Figs. 3 and 4) suggest either a shallowing of the lysocline or dissolution above the lysocline. Curry and Cullen (1997) have documented high carbonate dissolution during glacial periods in response to deep water mass changes at greater depths in the WTA (>3000 m water depth). Owing to the shallow depth po- 
sition of Core MD03-2616, dissolution below the lysocline is less probable, because aragonite and calcite lysoclines have been reported at 2200 and $4000 \mathrm{~m}$, respectively (in Vink et al., 2001). Dissolution above the lysocline may be a response to the acidification of interstitial waters due to the oxidation of organic matter within the sediments.

5 However, this hypothesis is not supported by the available observations, and hence its confirmation requires detailed benthonic isotope $\delta^{13} \mathrm{C}$ data, sedimentological studies, and further oceanographic reconstructions in the Guyana Basin.

\section{Conclusions}

Variations in the evolution of calcareous nannofossils have allowed us to elucidate 10 changes in the oceanic and atmospheric dynamics in the Guyana Basin; such changes are primarily linked to the southeast Trade Winds.

The data on the accumulation rate of coccoliths (NAR) resemble those of the $N$ ratio when dissolution is lacking, suggesting a close connection between the production of calcareous nannoplankton and the accumulation of coccoliths. Higher values

15 of the $N$ ratio and NAR during interglacials are linked to a persistent shallow nutrithermocline, in contrast to low $N$ and NAR values during glacials, which indicate a deep nutri-thermocline. A shallow nutri-thermocline gives rise to more surface nutrientenriched waters during Termination II and interglacial substages of MIS 5.1 and 5.3, involving more productive conditions. By contrast, a deep nutri-thermocline reveals 20 deep stratified conditions during the glacial substages of MIS 5 and MIS 2-4.

The greater productivity of calcareous nannoplankton was due to the upwelling of cool waters from depth (termination II and interglacial substages of MIS 5), which is consistent with the enhanced southeast Trade Winds that blew parallel to the coast and displaced the ITCZ to a more northerly position, while deep stratified conditions 25 would have resulted from weakened southeast Trade Winds and enhanced northeast Trade Winds. Northeast Trade Winds allowed the southward displacement of the ITCZ and blew perpendicularly to the coast, piling up waters transported by the NEC and re-

ducing upwelling. However, the influence of continental-derived nutrients and a freshening of surface water masses in the ocean through Amazon River runoff cannot be discarded.

The production of calcareous nannoplankton and the shifting of the nutri-thermocline 5 covary with insolation at high northern latitudes: a high $N$ ratio and a high NAR occurred during periods of high northern insolation (interglacials) and viceversa. Such variations are in agreement with an intensification (weakening) of the southeast Trade Wind dynamics and with the northern (southern) latitudinal migration of the ITCZ that activated (reduced) the upwelling system at the continental margin of the Guyana Basin. 


\section{Appendix A}

\section{Taxonomic appendix}

Calcidiscus leptoporus Calciosolenia murrayi Coccolithus pelagicus Emiliania huxleyi Florisphaera profunda Gephyrocapsa aperta Gephyrocapsa ericsonii Gephyrocapsa caribbeanica Gephyrocapsa muellerae Gephyrocapsa oceanica Hayaster perplexus Helicosphaera carteri Neosphaera coccolithomorpha Oolithotus

Oolithotus antillarum

Pontosphaera

Pseudoemiliania lacunosa Rhabdosphaera clavigera Reticulofenestra

Syracosphaera

Syracosphaera lamina

Syracosphaera pulchra

Umbellosphaera

Umbilicosphaera hulburtiana

Umbilicosphaera sibogae var. foliosa

Umbilicosphaera sibogae var. sibogae
(Murray and Blackman, 1898) Loeblich and Tappan, 1978

Gran, 1912

(Wallich, 1877) Schiller, 1930

(Lohmann, 1902) Hay and Mohler in Hay et al., 1967

Okada and Honjo, 1973

Kamptner, 1963

Mclntyre and Bé, 1967

Boudreaux and Hay, 1967

Bréhéret, 1978

Kamptner, 1943

(Bramlette and Riedel 1954) Bukry 1973

(Wallich, 1877) Kamptner, 1954

Lecal-Schlauder, 1950

(Cohen, 1964) Reinhardt, in Cohen and Reinhardt, 1968

Reinhardt, in Cohen and Reinhardt, 1968

Lohmann, 1902

(Kamptner 1963) Gartner 1969

(Murray and Blackman, 1898)

Hay, Mohler and Wade 1966

Lohmann, 1902

Lecal-Schlauder 1951

Lohmann, 1902

Paasche, in Markali and Paasche, 1955

Gaarder, 1970

(Kamptner, 1963) Okada and McIntyre, 1977

(Weber-van Bosse, 1901) Gaarder, 1970

\section{Appendix B}

\section{Taxonomic information}

The systematic classification of coccoliths is based on their morphology. The mor5 phological differences used for the genus Gephyrocapsa were adopted from Flores et al. (2000) and are summarised in Appendix C. Small placoliths (such as Gephyrocapsa aperta and G. ericsonii, small Reticulofenestra and Emiliania huxleyi) with an open or closed central area and smaller than $3 \mu \mathrm{m}$ were classified together in the group of small Noelaerhabdaceae. Gephyrocapsa spp. contain Gephyrocapsa species larger

10 than $3 \mu \mathrm{m}$ such as $G$. oceanica, G. muellerae, and G. caribbeanica. Different sizes of G. oceanica were also considered for carbonate calculations (medium Gephyrocapsa 3-4 $\mu \mathrm{m}$ and large Gephyrocapsa $4-5 \mu \mathrm{m}$ ), but later on these sizes were lumped together as G. oceanica for paleoecological purposes. Additionally, Oolithotus spp., Pontosphaera spp., Rhabdosphaera clavigera, Syracosphaera spp., Umbellosphaera

15 spp. and Umbilicosphaera spp. were included as the group of warm taxa (Hiramatsu and De Deckker, 1997; Boeckel and Baumann, 2004). The genus Umbilicosphaera includes U. hulburtiana, U. sibogae var. foliosa and U. sibogae var. sibogae (the latter species here designated $U$. sibogae). The marked dominance of Umbilicosphaera sibogae in the group of the warm taxa suggests that its paleoecological behaviour in Guyana Basin should be analyzed. Calcidiscus leptoporus and Helicosphaera spp. species are characterized by their lower abundances and poor consistence along the record studied. Helicosphaera spp. mainly include Helicosphaera carteri and in a lower proportion $H$. pavimentum (below 1\%). 
Taxonomic notes and morphological differences used for the genus Gephyrocapsa (mainly adopted from Flores et al., 2000) in this study.

\begin{tabular}{|c|c|c|c|c|}
\hline This Study & $\begin{array}{l}\text { Small Gephyrocapsa } \\
\text { (G. ericsonii and G.aperta) }\end{array}$ & $\begin{array}{l}\text { G. muellerae } \\
\text { (it includes G. margereli) }\end{array}$ & G. caribbeanica & $\begin{array}{l}\text { G. oceanica (G. oceanica } \\
\text { and large Gephyrocapsa) }\end{array}$ \\
\hline Coccolith length & $<3 \mathrm{~mm}$ & $>3 \mu \mathrm{m}$ & $>3 \mu \mathrm{m}$ & $3-5 \mu \mathrm{m}(3-4 \mu \mathrm{m}$ and $4-5 \mu \mathrm{m})$ \\
\hline \multicolumn{5}{|l|}{ Author equivalence } \\
\hline Thierstein et al., 1977 & & G. caribbeanica & & \\
\hline Raffi et al., 1993 & Small Gephyrocapsa & Small Gephyrocapsa & Small Gephyrocapsa & Medium Gephyrocapsa \\
\hline Bollmann, 1997 & G. minute & G. cold & G. oligotrophic, G. transitional & G. large, G. equatorial \\
\hline Flores et al., 2000 & Small Gephyrocapsa & G. muellerae & G. caribbeanica & G. oceanica \\
\hline Baumann and Freitag, 2004 & G. ericsonii/G. aperta & G. muellerae/G. margereli & G. caribbeanica & G. oceanica \\
\hline
\end{tabular}

Acknowledgements. The research discussed here was supported by Spanish projects CGL2005-00642/BTE, CGL2006-10593 from the Ministerio de Educación y Ciencia, A008C05 from the Consejería de Educación de la Junta de Castilla y León and by the Spanish Grant BES-2003-0010 from the Ministerio de Educación y Ciencia to G.-E. López-Otálvaro. We also 10 gratefully thank M. A. Bassetti and one anonymous reviewer for their useful comments.

\section{References}

Balsam, W. L., Otto-Bliesner, B. L., and Deaton, B. C.: Modern and last glacial maximum eolian sedimentation patterns in the Atlantic Ocean interpreted from iron oxide content, $\mathrm{Pa}-$ leoceanography, 10, 493-507, 1995.

15 Bassinot, F. C., Beaufort, L., Vincent, E., and Labeyrie, L.: Changes in the dynamics of Western Equatorial Atlantic surface currents and biogenic productivity at the "Mid-Pleistocene RevoIution" ( 930 Ka), in: Proc. ODP, edited by: Shackleton, N. J., Curry, W. B., Richter, C., and Bralower, T. J., Sci. Results, 154, College Station, TX (Ocean Drilling Program), 269-284, 1997.

Baumann, K.-H. and Freitag, T.: Pleistocene fluctuations in the northern Benguela Current systems as revealed by coccolith assemblages, Mar. Micropaleontol., 52, 195-215, 2004.

Beaufort, L., Lancelot, Y., Camberlin, P., Cayre, O., Vincent, E., Bassinot, F., and Labeyrie, L.:

Insolation Cycles as a Major Control of Equatorial Indian Ocean Primary Production, Science 278, 1451-1454, 1997.

Beaufort, L., Bassinot, F. C., and Vincent, E.: Primary production response to orbitally induced variations of the Southern Oscillation in the Equatorial Indian Ocean, in: Reconstructing

5 Ocean History: a Window into the Future, edited by: Abrantes, F. and Mix, A. C., Kluwer Academic/Plenum, New York, 245-272, 1999.

Beaufort, L., de Garidel-Thoron, T., Mix, A. C., and Pisias, N. G.: ENSO-like Forcing on Oceanic Primary Production During the Late Pleistocene, Science 293, 2440-2444, 2001.

Beaufort, L. and Buchet, N.: Variability of specific coccolith $\mathrm{CaCO}_{3}$ weight, and primary pro-

10 duction in the western Pacific warm pool during the last glacial cycle, Geophysical Research Abstracts (European Geosciences Union) 5, 13225, 2003.

Beaufort, L., de Garidel-Thoron, T., Linsley B., Oppo D., and Buchet N.: Biomass burning and oceanic primary production estimates in the Sulu Sea area over the last $380 \mathrm{Ky}$ and the East Asian monsoon dynamics, Mar. Geol., 201, 53-65, 2003.

15 Böeckel, B. and Baumann, K.-H.: Distribution of coccoliths in surface sediments of the southeastern South Atlantic Ocean: ecology, preservation and carbonate contribution, Mar. Micropaleontology, 51, 301-320, 2004.

Bollmann, L., Baumann, K.-H., and Thierstein, H. R.: Global dominance of Gephyrocapsa coccoliths in the Late Pleistocene: Selective dissolution, evolution or global environment change, Paleoceanography 13, 517-529, 1998.

Brand, L. E.: Physiological ecology of marine coccolithophores, in: Coccolithophores, edited by: Winter, A. and Siesser, W. G., Cambridge Univ. Press, Cambridge, UK, 3949, 1994.

Busalacchi, A. and Picaut, J.: Seasonal variability from a model of the tropical Atlantic Ocean, J. Phys. Oceanogr., 13, 1564-1588, 1983.

25 Curry, W. B. and Cullen, J. L.: Carbonate production and dissolution in the western equatorial Atlantic during the last 1 M.Y, in: Proc. ODP, edited by: Shackleton, N. J., Curry, W. B., Richter, C., and Bralower, T. J., Sci. Results, 154: College Station, TX (Ocean Drilling Program), 189-199, 1997.

da Silveira, I. C. A., de Miranda, L. B., and Brown, W. S.: On the origins of the North Brazil

$30 \quad$ Current, J. Geophys. Res., 99, 22 501-22 512, 1994.

de Menocal, P. B.: Plio-Pleistocene African Climate, Science, 270, 53-59, 1995.

Dittert, N., Baumann, K.-H., Bickert, R., Henrich, R., Huber, R., Kinkel, H., and Meggers, $\mathrm{H}$.: Carbonate dissolution in the deep-sea: methods, quantification and paleoceanographic 
application, in: Use of Proxies in Paleoceanography: Examples from the South Atlantic, edited by; Fischer, G. and Wefer, G., Springer Verlag, Berlin, Heidelberg, 255-284, 1999.

Ericson, D. B. and Wollin, G.: Correlation of six cores from the equatorial Atlantic and the Caribbean, Deep-Sea Res., 3, 104-125, 1956.

5 Ffield, A.: North Brazil current rings viewed by TRMM Microwave Imager SST and the influence of the Amazon Plume, Deep-Sea Res. Pt. I, 52, 137-160, 2005.

Flores, J. A. and Sierro, F. J.: Revised technique for calculation of calcareous nannofossil accumulation rates, Micropaleontology, 43, 321-324, 1997.

Flores, J.-A., Gersonde, R., and Sierro, F.-J.: Pleistocene fluctuations in the Agulhas Current Retroflection based on the calcareous plankton record, Mar. Micropaleontol., 37, 1-22, 1999.

Flores, J. A., Bárcena, M. A., and Sierro, F. J.: Ocean-surface and wind dynamics in the Atlantic Ocean off Northwest Africa during the last 140000 years, Palaeogeogr. Palaeocl., 161, 459478, 2000.

15 Flores, J. A., Marino, M., Sierro, F. J., Hodell, D. A., and Charles, C. D.: Calcareous plankton dissolution pattern and coccolithophore assemblages during the last $600 \mathrm{kyr}$ at ODP Site 1089 (Cape Basin, South Atlantic): paleoceanographic implications, Palaeogeogr. Palaeocl., 196, 409-426, 2003.

Gibbs, R. J.: Wind-controlled coastal upwelling in the western equatorial Atlantic, Deep-Sea Res., 27A, 857-866, 1980.

Gibbs, S., Shackleton, N., and Young, J.: Orbitally forced climate signals in mid-Pliocene nannofossil assemblages, Mar. Micropaleontol., 51, 9-56, 2004.

Giraudeau, J.: Distribution of Recent nannofossils beneath the Benguela system: Southwest African continental margin, Mar. Geol., 108, 219-237, 1992.

25 Hagino, K. and Okada, H.: Floral response of coccolithophores to progressive oligotrophication in the South Equatorial Current, Pacific Ocean, in: Global Environmental Change in the Ocean and on Land, edited by: Shiyomi, M., Kawahata, H., Koizumi, H., Tsuda, A., and Awaya, Y., TERRAPUB, 121-132, 2004.

Hastenrath, S. and Druyan, L.: Circulation anomaly mechanisms in the tropical Atlantic sector during the Northeast Brazil rainy season: results from the GISS General Circulation Model, J. Geophys. Res.-Atmos., 98(D8), 14 017-14 923, 1993.

Hastenrath, S. and Greischar, L.: Circulation mechanisms related to Northeast Brazil rainfall anomalies, J. Geophys. Res.-Atmos., 98(D5), 5093-5102, 1993.

Hastenrath, S. and Merle, J.: Annual cycle of subsurface thermal structure in the tropical Atlantic ocean, J. Physical Research, 17, 1518-1538, 1987.

Haug, G. H., Hughen, K. A., Sigman, D. M., Peterson, L. C., and Röhl, U.: Southward migration of the Intertropical Convergence Zone through the Holocene, Science, 293, 1304-1308, 2001.

Haug, G. H., Günther, D., Peterson, L. C., Sigman, D. M., Hughen, K. A., and Aeschlimann, B.: Climate and the collapse of Maya Civilization, Science, 299, 1731-1735, 2003.

Hibberd, D. J.: The ultrastructure and taxonomy of the Chrysophyceae and Prymnesiophyceae (Haptophyceae): a survey with some new observations on the ultrastructure of the Chrysophyceae, Bot. J. Linn. Soc., 72, 55-80, 1976.

Hiramatsu, C. and De Deckker, P.: The late Quaternary calcareous nannoplankton assemblages from three cores from the Tasman Sea, Palaeogeogr. Palaeocl. 131, 391-412, 1997.

Hulburt, E. M. and Corwin, N.: Influence of the Amazon River outflow on the ecology of the western tropical Atlantic: III. The planktonic flora between the Amazon River and the Windward islands, J. Mar. Res., 27, 55-72, 1969.

Hüls, M. and Zahn, R.: Millennial-scale sea surface temperature variability in the western tropical North Atlantic from planktonic foraminiferal census counts, Paleoceanography, 15, 659$678,2000$.

Kennett, J. P. and Huddlestun, P.: Late Pleistocene Paleoclimatology, foraminiferal biostratigraphy and tephrochronology, western Gulf of Mexico, Quaternary Res., 2, 38-69, 1972.

Kinkel, H., Baumann, K.-H., and epek, M.: Coccolithophores in the equatorial Atlantic Ocean: response to seasonal and Late Quaternary surface water variability, Mar. Micropaleontol., $39,87-112,2000$.

Kolla, V., Biscaye, P. E., and Hanley, A. F.: Distribution of quartz in late Quaternary Atlantic sediments in relation to climate, Quaternary Res., 11, 261-277, 1979, 1979.

Lazar, A., Inui, T., Malanotte-Rizzoli, P., Busalacchi, A. J., Wang, L., and Murtugudde, R.: Seasonality of the ventilation of the tropical Atlantic thermocline in an ocean general circulation model, J. Geophys. Res., 107, (C8), 3104, doi:10.1029/2000JC000667, 2002.

Lisiecki, L. E. and Raymo, M. E.: A Pliocene-Pleistocene stack of 57 globally distributed benthic $\delta^{18}$ O records, Paleoceanography, 20, doi:10.1029/2004PA001071, 2005.

Liu, Z. and Herbert, T.: High-latitude on the Eastern Equatorial Pacific climate in the early Pleistocene epoch, Nature, 427, 720-723, 2004.

López-Otálvaro, G.-E., Flores, J.-A., Sierro, F.-J., and Cacho, I.: Variations in coccolithophorid 
production in the Eastern Equatorial Pacific at ODP Site 1240 over the last seven glacialinterglacial cycles, Mar. Micropaleontol., doi: 10.1016/j.marmicro.2007.11.009, 2008.

Lynch-Stieglitz, J., Curry, W. B., and Slowey, N.: Weaker Gulf Stream in the Florida Straits during the Last Glacial Maximum, Nature, 402, 644-648, 1999.

5 Manabe, S. and Broccoli, J.: The influence of continental ice sheets on the climate of an ice age, J. Geophys. Res., 90, 2167-2190, 1985.

Marsh, M. E.: Regulation of $\mathrm{CaCO}_{3}$ formation in coccolithophores, Comp. Biochem. Physiol., 136, 743-754, 2003.

Martínez, J. I., Mora, G., and Barrows, T. T.: Paleoceanographic conditions in the western Caribbean Sea for the last $560 \mathrm{Ka}$ as inferred from planktonic foraminifera, Mar. Micropaleontol., 64, 177-188, 2007.

Masson, S. and Delecluse, P.: Influence of the Amazon river runoff on the tropical Atlantic, Phys. Chem. Earth, 26, 137-142, 2000.

Maslin, M. and Mikkelsen, N.: Amazon Fan mass transport deposits and underlying interglacial

15 deposits: age estimates and fan dynamics, in: Proc. ODP, edited by: Flood, R. D., Piper, D. W. J., Klauss, A., and Peterson, L. C., Sci. Results, 155, College Station, TX (Ocean Drilling Program), 353-365, 1997.

Mclntyre, A and Bé, A. W. H.: Modern Coccolithophoridae of the Atlantic Ocean-1. Placoliths and cyrtoliths, Deep-Sea Res., 14, 561-597, 1967.

20 Milliman, J. D.: Production and accumulation of calcium carbonate in the ocean: budget of an unsteady state, Global Biogeochem. Cy., 7, 927-957, 1993.

Mitchell-Innes, B. A. and Winter, A.: Coccolithophores: a major phytoplankton component in mature upwelled waters off the Cape Peninsula, South Africa in March, 1983, Mar. Biol., 95, 25-30, 1987.

25 Molfino, B. and Mclntyre, A.: Precessional forcing of nutricline dynamics in the equatorial Atlantic, Science, 249, 766-769, 1990a.

Molfino, B. and Mclntyre, A.: Nutricline variation in the equatorial Atlantic coinciding with the Younger Dryas, Paleoceanography, 5, 997-1008, 1990b.

Müller-Karger, F. E., McClain, C. R., and Richardson, P. L.: The dispersal's of the amazon water, Nature, 333, 56-59, 1988.

Müller-Karger, F. E, McClain, C. R., Fisher, T. R., Esaias, W. E., and Varela, R.: Pigment distribution in the Caribbean Sea, Prog. Oceanogr., 23, 23-64, 1989.

Müller-Karger, F. E., and Aparicio-Castro, R.: Mesoscale processes affecting phytoplancton

abundance in the southern Caribbean Sea, Cont. Shelf Res., 14, 199-221, 1994.

Müller-Karger, F. E., Richardson, P. L., and McGillicuddy, D.: On the offshore dispersal of the Amazon's Plume in the North Atlantic: Comments on the paper by A. Longhurst, "Seasonal cooling and blooming in tropical oceans", Deep-Sea Res. Pt. I, 42, 2127-2137, 1995.

5 Okada, H.: Calcareous nannofossils from Deep Sea Drilling Project Sites 442 through 446, Philippines Sea. Init. Rep. DSDP, 58, 549-565, 1980.

Okada, H. and Honjo, S.: The distribution of oceanic coccolithophorids in the Pacific, Deep-Sea Res., 20, 355-374, 1973.

Okada, H. and Mclntyre, A.: Modern coccolithophores of the Pacific and North Atlantic Oceans, Micropaleontology, 23, 1-55, 1977.

Okada, H. and McIntyre, A.: Seasonal distribution of modern Coccolithophores in the Western North Atlantic ocean, Mar. Biol., 54, 319-328, 1979.

Okada, H. and Wells, P.: Late Quaternary nannofossil indicators of climate change in two deep-sea cores associated with the Leeuwin Current off Western Australia, Palaeogeogr. Palaeocl., 131, 413-432, 1997.

Pailler, K., Bourlès, B., and Gouriou, Y. : The Barrier layer in the Western tropical Atlantic Ocean, Geophys. Res. Lett., 26, 2069-2072, 1999.

Peterson, L. C., Haug, G. H., Hughen, K. A., and Röhl, U.: Rapid changes in the hydrologic cycle of the Tropical Atlantic during the Last Glacial, Science, 290, 1947-1951, 2000.

20 Prell, W. L. and Damuth, J. E.: The climate-related diachronous disappearance of Pulleniatina obliquiloculata in Late Quaternary sediments of the Atlantic and Caribbean, Mar. Micropaleontol., 3, 267-277, 1978.

Pujos, M., and Froidefond, J.-M.: Water masses and suspended matter circulation on the French Guiana continental shelf, Cont. Shelf Res., 15, 1157-1171, 1995.

25 Richardson, P. L., Hufford, G., Limeburner, R., and Brown, W.: North Brazil Current retroflection eddies, J. Geophys. Res., 99, 5081-5093, 1994.

Roth, P. H.: Distribution of coccoliths in ocean sediments, in: Coccolithophores, edited by: Winter, A. and Siesser, W. G., Cambridge University Press, Cambridge, 199-218, 1994.

Roth, P. H. and Berger, W. H.: Distribution and dissolution of coccoliths in the South and central

$30 \quad$ Pacific, Special Publications vol. 13, Cushman Foundation for Foraminiferal Research, 87113, 1975.

Roth, P. H. and Colbourn, W. T.: Floral and solution patterns of coccoliths in surface sediments of the North Pacific, Mar. Micropaleontol., 7, 1-52, 1982. 
Ruddiman, W. F. and McIntyre, A.: Ice-age thermal response and climatic role of the surface Atlantic Ocean, $40^{\circ}$ to $63^{\circ} \mathrm{N}$, Geol. Soc. Am. Bull., 95, 381-396, 1984.

Ruddiman, W. F., Raymo, M. E., Martinson, D. G., Clement, B. M., and Backman, J.: Pleistocene evolution: Northern hemisphere ice sheets and North Atlantic ocean, Paleoceanography, 4, 353-412, 1989.

Ryther, J. H., Menzel, D. W., and Corwin, N.: Influence of the Amazon River outflow on the ecology of the western tropical Atlantic: I. Hydrography and nutrient chemistry, J. Mar. Res., 25, 69-83, 1967.

Schmitz, W. J. Jr.: On the interbasin-scale thermohaline circulation, Rev. Geophys., 33, 151173, 1995.

Shipboard Scientific Party: MD132-PICASSO, IMAGES XI. Cruise Report, p. 76, 2003.

Showers, W. J. and Bevis, M.: Amazon cone isotopic stratigraphy: evidence for the source of the tropical freshwater spike, Palaeogeogr. Palaeocl., 64, 189-199, 1988.

Siesser, W. and Winter, A.: Composition and morphology of coccolithophore skeletons, in: Coc-

15 colithophores, edited by: Winter, A. and Siesser, W. G., Cambridge Univ. Press, Cambridge, UK, 51-62, 1994.

Steinmetz, J. C.: Sedimentation of coccolithophores, in: Coccolithophores, edited by: Winter, A., Siesser, W.G., Cambridge University Press, Cambridge, 179-197, 1994.

Stramma, L. and Schott, F.: Western equatorial circulation and interhemispheric exchange, in: The warm water sphere of the North Atlantic Ocean, edited by: Krauss, W., Gebrüder Borntraeger, Berlin, Stuttgart, 195-227, 1996.

Stramma, L., Fischer, J., and Reppin, J.: The North Brazil Undercurrent, Deep-Sea Res., 42, 773-795, 1995.

Stramma, L., Rhein, M., Brandt, P., Dengler, M., Böning, C., and Walter, M.: Upper ocean circulation in the western tropical Atlantic in boreal fall 2000, Deep-Sea Res. Pt. I, 52, $221-$ 240, 2005.

$\mathrm{Su}, \mathrm{X}$.: Development of late tertiary and quaternary coccolith assemblages in the Northeast Atlantic, GEOMAR-Report 48, 119, 1996.

Thierstein, H. R., Geitzenauer, K., Molfino, B., and Shackleton, N. J.: Global synchroneity of

30 late Quaternary coccolith datum levels: validation by oxygen isotopes, Geology, 5, 400-404, 1977.

Vink, A., Zonneveld, K. A. F., and Willems, H.: Distributions of calcareous dinoflagellate cysts in surface sediments of the western equatorial Atlantic Ocean, and their potential use in

paleoceanography, Mar. Micropaleontol., 38, 149-180, 2000.

Vink, A., Rühlemann, C., Zonneveld, K., Mulitza, S., Hüls, M., and Willems, H.: Shifts in the position of North Equatorial current and rapid productivity changes in the western Tropical Atlantic during the last glacial, Paleoceanography, 16, 1-12, 2001.

5 Vink, A., Brune, C. H., Zonnevveld, K. A. F., and Willems, H.: On the response of calcareous dinoflagellates to oligotrophy and stratification of the upper water column in the equatorial Atlantic Ocean, Palaeogeogr. Palaeocl., 178, 53-76, 2002.

Wells, P. and Okada, H.: Response of nannoplankton to major changes in sea-surface temperature and movements of hydrological fronts over Site DSDP 594 (south Chatham Rise, southeastern New Zeland), during the last $130 \mathrm{Kyr}$, Mar. Micropaleontol., 32, 341-363, 1997.

Westbroek, P., Brown, C. W., Van Bleijswijk, J., Brownlee, C., Brummer, G. J., Conte, M., Egge, J., Fernández, E., Jordan, R., Knappertsbusch, M., Stefels, J., Veldhuis, M., Van Der Waal, P., and Young, J. R.: A model system approach to biological climate forcing. The example of Emiliania huxleyi, Global Planet. Change, 8, 27-46, 1993.

15 Wilson, W. D., Johns, W. E., and Garzioli, S. L.: Velocity structure of North Brazil current rings, Gephys. Res. Lett., 29(8), 1273, doi: 1029/2001GL013869, 2002.

Winter, A.: Paleoenvironmental interpretation of Quaternary coccolith assemblages from the Gulf of Aqaba (Elat), Red Sea. Revista Española de Micropaleontología, 14, 291-314, 1982.

Winter, A.: Distribution of living coccolithophores in the California Current system, southern California borderland, Mar. Micropaleontol., 9, 385-393, 1985.

Winter, A., Jordan, R. W., and Roth, P.: Biogeography of living coccolithophores in ocean waters, in: Coccolithophores, edited by: Winter, A. and Siesser, W. G., Cambridge University Press, Cambridge, 161-177, 1994.

Wolff, T., Multiza, S., Rühlemann, C., and Wefer, G.: Response of the tropical Atlantic thermocline to late Quaternary trade wind changes, Paleoceanography, 14, 374-383, 1999.

Young, J. R.: Functions of coccoliths, in: Coccolithophores, edited by: Winter, A. and Siesser, W. G., Cambridge University Press, Cambridge, 63-82, 1994.

Ziveri, P., Baumann, K.-H., Böeckel, B., Bollman, J., and Young, J.: Present day coccolithophore-biogeography in the Atlantic Ocean, in: Coccolithophores: From Molecu-

30 lar Processes to Global Impact., edited by: Thierstein, H. and Young, J., Springer-Verlag, 403-428, 2004. 

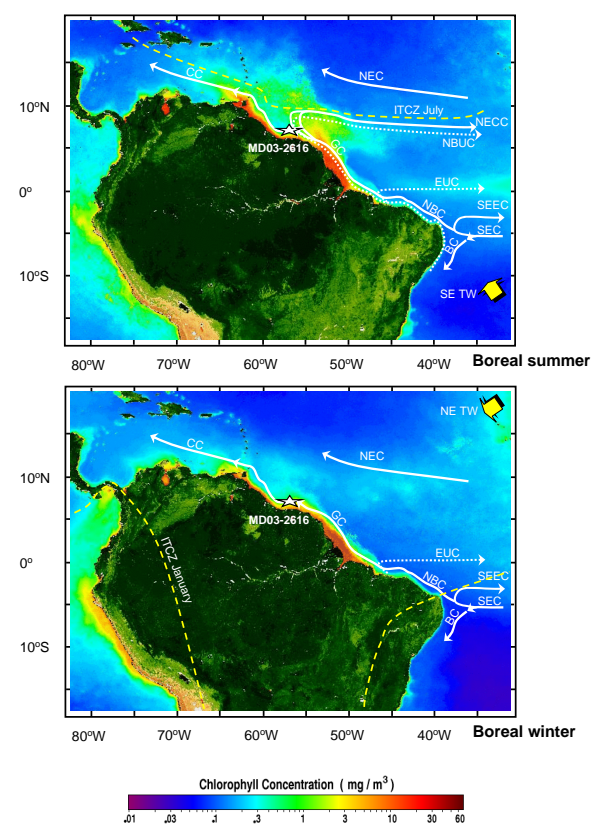

Fig. 1. Satellite images acquired by the SEAWIFS Program at the location of the Core MD032616. Hydrographic and atmospheric features in WTA: Surface currents are indicated by continuous lines and subsurface currents are indicated by dotted lines. SEC: South Equatorial Current, BC: Brazilian Current, NBC: North Brazilian Current, CC: Caribbean Current, NECC: North Equatorial Counter Current, SECC: South Equatorial Counter Current, EUC: Equatorial Undercurrent, NBCU: North Brazilian Countercurrent, ITCZ: Intertropical Convergence Zone. (Adopted from http://oceancolor.gsfc.nasa.gov/SeaWiFS; Richardson et al., 1994 and Haug et al., 2003.)

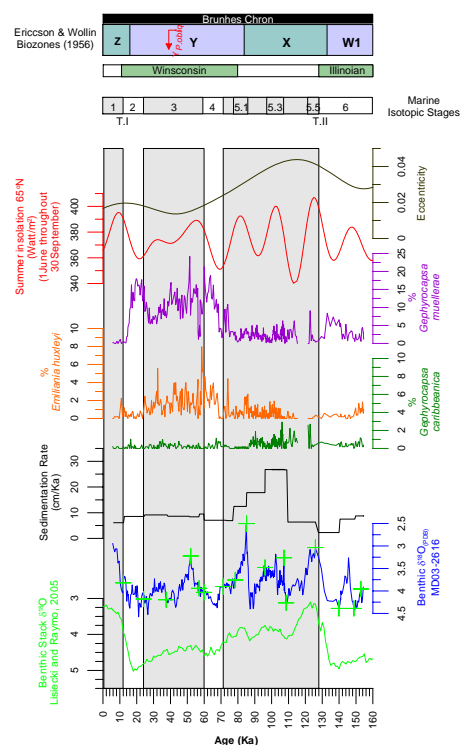

Fig. 2. Benthic $\delta^{18} \mathrm{O}$ stack record (Lisiecki and Raymo, 2005), benthic $\delta^{18} \mathrm{O}$ record from Core MD03-2616 (López-Otálvaro et al. 2008), sedimentation rates at Core MD03-2616 and the relative abundance of the specific index species from calcareous nannofossils at Core MD032616. The biozones $X, Y, Z$ and $W$ represent the biostratigraphic events from planktonic foraminifers identified at Core MD03-2616. The $Y_{\text {P.obliq. }}$ biozone corresponds to the disappearance of Pulleniatina obliquiloculata. Las cruces verdes in the $\delta{ }^{18} \mathrm{O}$ record from Core MD032616 correspond to the control points used for constructing the chronostratigraphic framework at Core MD03-2616. Grey bars indicate interglacial marine isotope stages 1 throughout 5. MIS $5.1,5.2,5.3,5.4,5.5$ correspond to the substages of MIS 5 . Wisconsin and Illinoian episodes correspond to the Ice Ages between $12 \mathrm{Ka}$ and $80 \mathrm{Ka}$ in the former, and $128 \mathrm{Ka}$ and $310 \mathrm{Ka}$ in the later. T.I=Termination I, T.II=Termination II. 


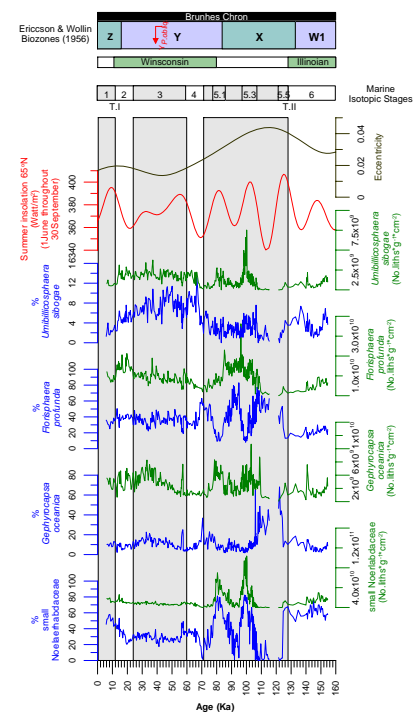

Fig. 3. Relative calcareous nannofossil abundances (\%) and nannofossil accumulation rates (NAR, liths ${ }^{*} \mathrm{gr}^{-1 *} \mathrm{~cm}^{-2}$ ) of the most significant species. Grey bars indicate interglacial marine isotope stages 1 throughout 5. MIS 5.1, 5.2, 5.3, 5.4, 5.5 correspond to the substages of MIS 5. Wisconsin and Illinoian episodes correspond to the Ice Ages between $12 \mathrm{Ka}$ and $80 \mathrm{Ka}$ in the former, and $128 \mathrm{Ka}$ and $310 \mathrm{Ka}$ in the later. T.I=Termination I, T.II=Termination II.

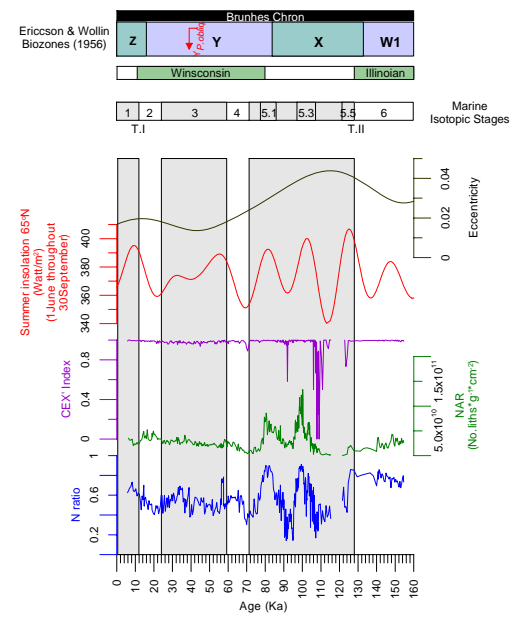

Fig. 4. Review of the bioproductivity proxies used for Core MD03-2616: $N$ ratio vs. total nannofossil accumulation rates (NAR, liths ${ }^{*} \mathrm{gr}^{-1 *} \mathrm{~cm}^{-2}$ ). Grey bars indicate interglacial marine isotope stages 1 throughout 5 . MIS 5.1, 5.2, 5.3, 5.4, 5.5 correspond to the substages of MIS 5 . Wisconsin and Illinoian episodes correspond to the Ice Ages between $12 \mathrm{Ka}$ and $80 \mathrm{Ka}$ in the former, and $128 \mathrm{Ka}$ and $310 \mathrm{Ka}$ in the later. T.I=Termination I, T.II=Termination II. 